\title{
Pure and raw glycerol in the diet of broiler chickens, its effect on the production parameters and slaughter value
}

\author{
Pavel Suchý, Eva Straková, Leo Kroupa and Ivan Herzig \\ Department of Nutrition, Animal Husbandry, and Animal Hygiene, Faculty of Veterinary Hygiene and Ecology, \\ University of Veterinary and Pharmaceutical Sciences Brno, Czech Republic
}

\begin{abstract}
The experiment was performed with a total of 180 day-old, ROSS 308 combination, meat-type hybrid chickens that were divided according to sex into the control group ( $\mathrm{C} 1$ and $\mathrm{C} 2$ with 30 o and $300^{\circ}$, respectively) and two experimental groups: GLY-P1 and P2 with pure glycerol ( $30 \%$ and $300^{\circ}$ ), and GLY-R1 and R2 with raw glycerol (30\% and 30 $\left.0^{\circ}\right)$. The chickens received three feeding mixtures during the experiment: the pre-fattening mixture (BR 1) until Day 14, the fattening mixture (BR 2) from Day 15 to Day 30, and the post-fattening mixture from Day 31 to Day 40 (BR 3). $50 \%$ of the soybean oil in feeding mixtures used in the experimental groups (GLY-P and GLY-R) was replaced with pure or raw glycerol at a ratio of 1:2. The feed and water were available ad libitum for consumption. The mean live weight of both male and female chickens in experimental groups on Days 15 and 40 was statistically significantly higher $(P \leq 0.05, P \leq 0.01)$ than that in the control group. The consumption of the feeding mixture during the entire 40-day fattening period was higher in female and male chickens in experimental groups. The differences in the mean weight of processed carcass between the control and experimental groups were very significant $(P \leq 0.01)$. Glycerol obtained during rapeseed processing is a suitable source of energy and can be added in feeds designed for farm animals.
\end{abstract}

Keywords: broiler, soybean oil, glycerol, live weight gain, feed conversion, slaughter yield

\section{Zusammenfassung}

\section{Rein- und Rohglycerin im Futter von Broilern -} Auswirkungen auf Produktionsparameter und Schlachtleistung

180 Tage alte Masthybrid ROSS 308 Broiler wurden nach Geschlecht in eine Kontrollgruppe (C1 und C2) und zwei Versuchsgruppen (GLY-P1 und P2 mit Reinglycerin und GLY-R1 und R2 mit Rohglycerin) mit je 30 männlichen und weiblichen Tieren aufgeteilt. Während des Versuchs erhielten die Hühner drei Futtergemische: Vormästung (BR 1) bis zum 14. Tag, Mästung (BR 2) 15.-30. Tag und Nachmästung (BR 3) 31.-40. Tag. $50 \%$ des Sojaöls im Futtergemisch, das für die Testgruppen (GLY-P und GLY-R) verwendet wurde, wurde in einem Verhältnis von 1:2 durch Rein- oder Rohglycerin ersetzt. Futter und Wasser standen ad libidum zur Verfügung. Das durchschnittliche Lebendgewicht sowohl von männlichen als auch weiblichen Hühnern 
in den Versuchsgruppen am Tag 15 und 40 war signifikant höher $(P \leq 0,05 ; P \leq 0,01)$ als das in der Kontrollgruppe. Der Verzehr des Futtergemisches während der gesamten 40-tägigen Mastperiode war bei den weiblichen und männlichen Hühnern der Versuchsgruppen höher. Die Unterschiede im durchschnittlichen Gewicht der Schlachtkörper zwischen Kontroll- und Versuchsgruppen waren hochsignifikant $(P \leq 0,01)$. Glycerin, das bei der Rapsverarbeitung entsteht, ist eine geeignete Energiequelle und kann Futter, das für Nutztiere gedacht ist, zugesetzt werden.

Schlüsselwörter: Broiler, Sojaöl, Glycerin, Lebengewichtszunahme, Futterverwertung, Schlachtleistung

\section{Introduction}

The gradually increasing biodiesel production (rapeseed oil methylester) poses a problem of the utilization of glycerol which is a by-product of this technology. The production of one tonne of biodiesel yields $100 \mathrm{~kg}$ of raw glycerol. Since the amount of glycerol generated during the production of methylester exceeds the demand of chemical industry, new alternatives for its use are currently being sought. Animal production seems to be a promising field to use glycerol as a source of energy in relatively large amounts, ensuring the optimum way of its recycling at the same time. The use of glycerol in the nutrition of farm animals was first mentioned in the 1960s and 1970s. For example, some of the studies investigated the effect of dietary glycerol on reproduction of sows and on the composition of fatty acids in lipids in fat tissue (Nevillee et al. 1970, Demarne et al. 1977), or reported the use of glycerol in poultry nutrition and its effect on reproduction (Neville et al. 1971, Westfall \& Howarth 1976). The use of glycerol in feeds for chickens is reported by Renner \& Elcombe (1964), resp. Carew \& Foss (1974). Emmanuel et al. (1983) studied the effect of glycerol on the synthesis of glucose in fattened chickens whereas Lin et al. (1976) investigated the effect of glycerol on the activity of lipogenic enzymes and the synthesis of fatty acids.

According to most authors, the optimum level of glycerol in feeding mixtures for broiler chickens lies in a range of 5-10\% (Simon et al. 1996, Barteczko \& Kaminski 1999, Cerrate et al. 2006). When present at this level, raw glycerol showed a positive effect on performance characteristics, with no negative effect being observed on feed conversion. The dose of $25 \%$ of glycerol was associated with pathological changes in organs and had a negative effect on performance characteristics in broiler chickens (Simon et al. 1997). Dozier et al. (2008) supplemented the diet of broiler chickens with 3.6 and $9 \%$ of glycerol in individual phases of the fattening period, and monitored not only performance characteristics (feed intake, body weight) but also the intake and excretion of energy and nitrogen. They showed that the apparent metabolizable energy (ME) of glycerol is effectively utilized by broiler chickens and that glycerol can be used as a source of energy in the diets for broiler chickens. However, what still has to be specified is the acceptable level of residual methanol that originates from the separation of fatty acids in biodiesel production (Cerrate et al. 2006). One positive finding is that glycerol improves technological and hygienic quality of granules, as reported by Schröder \& Südekum (1999). Glycerol doses above $100 \mathrm{~g}$ per kg of feed can cause technological problems in the granulation of feeding mixtures. 
The main aim of the experiment was to investigate the effect of feed in which $50 \%$ of soybean oil was substituted with »pure« and »raw« glycerol in a ratio of 1:2 on production parameters, slaughter values and health state of broiler chickens.

\section{Material and methods}

The comparative feeding trial was performed on meat type ROSS 308 hybrid combinations of broiler chickens in the accredited experimental enclose of the Institute of Nutrition, Animal Husbandry, and Animal Hygiene, Faculty of Veterinary Hygiene and Ecology, University of Veterinary and Pharmaceutical Sciences, Brno, Czech Republic. The experiment involved 180 one-day-old chickens that were divided (according to gender) to C1 and C2 control groups (30\%

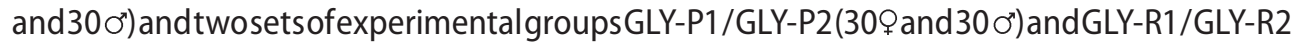
( 30 \% and $30 \mathrm{O}^{\mathrm{T}}$ ). Chickens in individual groups were kept separately in pens, on deep bedding, at a density of 1 chicken per $0.25 \mathrm{~m}^{2}$. The light regimen of $23 \mathrm{~h}$ of light and $1 \mathrm{~h}$ of dark was used throughout the fattening experiment. Temperature in enclosures equipped with a controlled microclimatic device was initially set to $31.5^{\circ} \mathrm{C}$ and decreased during the experiment to the final temperature of $22.5^{\circ} \mathrm{C}$. Chickens were fed in compliance with the technological procedure for ROSS 308 combination hybrid chickens. Chickens received three kinds of feeding mixtures in form of mash during the experiment: pre-fattening mixture (BR 1) from Day 1 to Day 14, fattening mixture from Day 15 to Day 30 (BR 2), and post-fattening mixture from Day 31 to Day 40 (BR 3). Feed was administered in self-feeders, water was provided from hat-shaped waterers, both were available ad libitum. Feeding mixtures were prepared in the Institute's mixing facility from a basic feeding mixture (Table 1), according to the procedure described below. $50 \%$ of soybean oil in feeding mixtures intended for experimental groups of chickens was replaced by glycerol at a ratio of 1:2, one portion of soybean oil was replaced by two portions of glycerol; pure glycerol was used in the GLY-P group whereas raw glycerol was used in the GLY-R group. Pure glycerol (E 422) contains $98 \%$ of glycerol (in dry matter). It is an additive as specified in Regulation No. 318/2003 (Anonymous 2003). Pure glycerol used in the experiment contained 15.3 MJ of gross energy (GE) per kg. Raw glycerol (feeding glycerin, bioglycerin) is generated in the glycerol phase processing during the production of rapeseed oil methylester. It is a viscous syrup-like liquid, having yellow to yellow-brown colour and a characteristic smell resembling raw materials, and contains $75-80 \%$ of glycerol. This product may contain a maximum of $9 \%$ of ash, $1.5 \%$ of non-volatile organic substances, $0.5 \%$ of residual methanol, the rest is water. Raw glycerol used in this experiment had $14.3 \mathrm{MJ}$ of GE per kg. Experimental feeding mixtures were prepared as follows:

- Group C $48.50 \mathrm{~kg}$ of basic feeding mixture $+1.50 \mathrm{~kg}$ of soybean oil.

- Groups GLY-P1 and P2 $47.75 \mathrm{~kg}$ of basic feeding mixture $+0.75 \mathrm{~kg}$ of soybean oil $+1.5 \mathrm{~kg}$ of pure glycerol.

- Groups GLY-R1 and R2 $47.75 \mathrm{~kg}$ of basic feeding mixture $+0.75 \mathrm{~kg}$ of soybean oil $+1.5 \mathrm{~kg}$ of raw glycerol.

Feeding mixtures were subjected to analysis prior to the comparative feeding experiment. Moisture content (dry matter) was determined gravimetrically on the basis of drying the sample at required conditions $\left(105^{\circ} \mathrm{C}\right)$. The content of nitrogen was determined by the 
Kjeldahl method using the Buchi analyser (Centec automatika, spol. s.r.o.). The content of nitrogen-containing substances present in the feed (raw protein) was determined multiplying the result by a coefficient of 6.25 . The content of fat was determined by extraction using ANKOMXT10 Fat Analyser (O.K. Servis BioPro). Raw fibre was determined using ANKOM220 Fibre Analyser (O.K. Servis BioPro). Ash content was determined gravimetrically after the combustion of a sample at a temperature of $550^{\circ} \mathrm{C}$ at defined conditions. Calcium, phosphorus, and magnesium were determined by combustion and extraction followed by titration. Non-nitrogen extractable substances (NNES) were calculated. Gross energy (MJ/ $\mathrm{kg}$ ) was determined in a bomb calorimeter in oxygen atmosphere using AC 500 (firma Leco), after the combustion of a sample.

Broilers were weighed individually throughout the experiment on Days 1, 15, 30 and 40, to monitor the development in their weight and evaluate the mean live weight gains in the individual phases of fattening. The consumption of feeding mixtures was recorded and used to calculate feed conversion. The state of chickens' health was monitored throughout the experiment and a mortality rate was recorded. After slaughter, the prepared carcass was analysed for carcass weight (CW) and carcass yield (CY) was calculated as a carcass/live weight ratio. Post mortem examination was carried out to evaluate the condition of internal organs, with particular attention being devoted to the liver. The weight of the liver and the liver yield (LY) (related to live weight) were determined for each chicken.

The results were processed using mathematical and statistical methods implemented in UNISTAT for Excel version 56, using the Tukey-HSD multiple comparison test. Differences between mean values were tested at the following levels of significance: $P \leq 0.01$ and $P \leq 0.05$ (ns: non-significant).

Table 1

The levels of individual components in basic feeding mixtures (BR1, BR2, BR3)

\begin{tabular}{lrrr}
\hline Components & BR 1 & BR 2 & BR 3 \\
\hline Wheat + energy supplement E & 41.70 & 47.80 & 47.20 \\
Maize 9\% NL & 15.00 & 15.00 & 20.00 \\
Soybean extracted meal 46\% NL & 35.80 & 29.60 & 24.90 \\
Biolys 65 & 0.58 & 0.46 & 0.24 \\
D,L-Methionine, 100\% & 0.30 & 0.25 & 0.20 \\
L-Threonine, 100\% & 0.12 & 0.08 & 0.05 \\
MCP - F & 1.18 & 1.00 & 0.90 \\
Feeding salt & 0.36 & 0.38 & 0.36 \\
Limestone, ground & 1.76 & 1.63 & 1.35 \\
Biofactor supplement & 0.20 & 0.20 & 0.20 \\
\hline
\end{tabular}

*The premix of specifically active substances used by the producer contained: vitamin A 1600000 IU; vitamin D3 500 000 IU; alpha-tocopherol 10000 mg; vitamin K3 300 mg; vitamin B1 800 mg; vitamin B2 1300 mg; vitamin B6 600 mg; vitamin B12 $3 \mathrm{mg}$; biotin $30 \mathrm{mg}$; folic acid $500 \mathrm{mg}$; niacinamide $6000 \mathrm{mg}$; calcium pantothenate $2500 \mathrm{mg}$; betaine 50 $000 \mathrm{mg}$; butylhydroxytoluene $3400 \mathrm{mg}$; propyl gallate $1200 \mathrm{mg}$; ethoxyquin $540 \mathrm{mg}$; ferrous sulphate monohydrate $10000 \mathrm{mg}$; manganese oxide $16000 \mathrm{mg}$; zinc oxide $16000 \mathrm{mg}$; copper sulphate $1700 \mathrm{mg}$; potassium iodide $200 \mathrm{mg}$; sodium selenite $30 \mathrm{mg}$; cobalt sulphate $50 \mathrm{mg}$; phytase $50000 \mathrm{FTU}$; glucanase 24000 BGU; xylanase 1100000 EXU 


\section{Results and discussion}

\section{The content of gross energy and water in different types of glycerol}

Gross energy (GE) and the content of water were determined in 10 samples of pure and raw glycerols and products made of glycerol (Glykomel and Laktosat). Individual types of glycerols differ in the content of GE and water. The values of GE ranged from 14.3 to $22.2 \mathrm{MJ} /$ $\mathrm{kg}$ in raw glycerol, and from 15.3 to $19.1 \mathrm{MJ} / \mathrm{kg}$ in pure glycerol. The content of water ranged from 104.6 to $250.7 \mathrm{~g} / \mathrm{kg}$ in raw glycerol and from 76.0 to $239.7 \mathrm{~g} / \mathrm{kg}$ in pure glycerol. The value of glycerols depends on the content of salt, residual methyl alcohol, the presence of free fatty acids, ash and water. The presence of such substances can affect the growth of chickens and feed conversion.

\section{Development of live weight in chickens}

Chickens' live weight was monitored during the experiment on Day 1, 15, 30 and 40. Higher weight was observed in chickens in the experimental groups, in both males and females. On Day 15 of fattening, the mean weight in the control group was $0.311 \mathrm{~kg}$ in females and $0.329 \mathrm{~kg}$ in males, whereas in the experimental groups (GLY-P and GLY-R) the mean weight was $0.413 \mathrm{~kg}$ and $0.410 \mathrm{~kg}$ in females and $0.429 \mathrm{~kg}$ and $0.427 \mathrm{~kg}$ in males. A statistically significant difference was found between the control group and the experimental groups $(P \leq 0.01)$ (Table 2). On Day 30, the difference between mean live weights in control and experimental groups were statistically non-significant although the trends were maintained. At the end of the experiment (Day 40), the weight of control females was $2.033 \mathrm{~kg}$ while the weight of females in the GLY-P experimental group was $2.224 \mathrm{~kg}$ and $2.185 \mathrm{~kg}$ in the GLY-R group; the difference between $C$ and GLY-P groups was statistically highly significant $(P \leq 0.01)$; the difference between the $C$ and GLY-R groups was statistically significant $(P \leq 0.05)$. The difference between the mean live weight of males in the $C$ group $(2.317 \mathrm{~kg})$ and the GLY-P group $(2.577 \mathrm{~kg})$ and group GLY-R $(2.555 \mathrm{~kg})$ was statistically significant $(P \leq 0.05)$. Average daily live weight gains in chickens in control and experimental groups in individual stages of fattening and throughout the experiment are provided in Table 3. The results obtained are in agreement with the findings reported by Simon et al. (1996), Barteczko \& Kaminski (1999), Cerrate et al. (2006) and Dozier et al. (2008). The replacement of soybean oil with glycerol in tested feeding mixtures had a favourable effect on the growth intensity in fattened chickens and resulted in increased mean daily weight gains in experimental chickens in both females and males. Experimental females showed a 9.4 and $7.5 \%$ increase in live weight as compared to control chickens. The live weight of males in experimental groups increased by 11.2 and $10.3 \%$ at the end of fattening, as compared to control. No significant difference in growth intensity was seen between the uses of pure or raw glycerol (Table 4). The results indicate that from Day 15 of fattening, the ratio of soybean oil/glycerol substitution might be increased from 1:2 to 1:2.6. This assumption is based on the value of $G E$, which was $15.3 \mathrm{MJ} / \mathrm{kg} B E$ for pure glycerol and $39.3 \mathrm{MJ} / \mathrm{kg}$ BE for soybean oil. Different types of glycerol are currently used in agricultural practice, the content of energy and other substances in these glycerols may affect performance characteristics. The content of energy in glycerol can change particularly in raw glycerols, depending on the content of water and other substances such as ash, 
residual methanol and free fatty acids, and can affect the growth intensity in chickens and feed conversion. The energy value of glycerol should be determined before its use in a diet and should serve as a starting point for the optimization of feed formulation.

Table 2

Mean live weight of chickens $(\mathrm{kg})$ in individual stages of fattening $(x \pm S D)$

\begin{tabular}{lrrrrrr}
\hline & \multicolumn{5}{c}{ Females } & \multicolumn{3}{c}{ Males } \\
Day & \multicolumn{1}{c}{$\mathrm{C}$} & \multicolumn{1}{c}{ GLY-P } & \multicolumn{1}{c}{ GLY-R } & \multicolumn{1}{c}{ C } & \multicolumn{1}{c}{ GLY-P } & \multicolumn{1}{c}{ GLY-R } \\
\hline 1 & $0.047 \pm 0.004$ & $0.049 \pm 0.005$ & $0.048 \pm 0.005$ & $0.049 \pm 0.004$ & $0.048 \pm 0.003$ & $0.048 \pm 0.004$ \\
15 & $0.311^{A B} \pm 0.087$ & $0.413 A \pm 0.046$ & $0.410^{\mathrm{B}} \pm 0.036$ & $0.329^{\mathrm{A}} \pm 0.084$ & $0.429^{\mathrm{A}} \pm 0.036$ & $0.427^{\mathrm{B}} \pm 0.051$ \\
30 & $1.369 \pm 0.239$ & $1.440 \pm 0.136$ & $1.412 \pm 0.121$ & $1.496 \pm 0.357$ & $1.624 \pm 0.163$ & $1.614 \pm 0.182$ \\
40 & $2.033^{\mathrm{Aa}} \pm 0.342$ & $2.224 \mathrm{~A} \pm 0.186$ & $2.185^{\mathrm{a}} \pm 0.160$ & $2.317^{\mathrm{ab}} \pm 0.438$ & $2.577^{\mathrm{a}} \pm 0.262$ & $2.555^{\mathrm{b}} \pm 0.287$ \\
\hline
\end{tabular}

${ }_{\mathrm{AA}, \mathrm{BB} P} P \leq 0.01,{ }^{\mathrm{a} a \mathrm{bb}} P \leq 0.05$

Table 3

Mean daily live weight gain in chickens in control and experimental groups in individual stages of fattening and throughout the experiment, $\mathrm{kg}(\mathrm{x} \pm \mathrm{SD})$

\begin{tabular}{|c|c|c|c|c|c|c|}
\hline \multirow[b]{2}{*}{ Days } & \multicolumn{3}{|c|}{ Females } & \multicolumn{3}{|c|}{ Males } \\
\hline & C & GLY-P & GLY-R & C & GLY-P & GLY-R \\
\hline $1-15$ & $0.018^{A B} \pm 0.0056$ & $0.024^{\mathrm{A}} \pm 0.0028$ & $0.024^{\mathrm{B}} \pm 0.0021$ & $0.019^{A B} \pm 0.0054$ & $0.025^{A} \pm 0.0022$ & $0.025^{\mathrm{B}} \pm 0.0031$ \\
\hline $15-30$ & $0.071 \pm 0.0105$ & $0.069 \pm 0.0062$ & $0.067 \pm 0.0057$ & $0.078 \pm 0.0184$ & $0.080 \pm 0.0086$ & $0.079 \pm 0.0088$ \\
\hline $30-40$ & $0.066^{\mathrm{AB}} \pm 0.0114$ & $0.078^{A} \pm 0.0052$ & $0.077^{B} \pm 0.0052$ & $0.082^{A B} \pm 0.0091$ & $0.095^{A} \pm 0.0104$ & $0.094^{B} \pm 0.0109$ \\
\hline $1-40$ & $0.050^{A B} \pm 0.0085$ & $0.054^{\mathrm{A}} \pm 0.0045$ & $0.053^{B} \pm 0.0039$ & $0.057^{\mathrm{Aa}} \pm 0.0109$ & $0.063^{A} \pm 0.0065$ & $0.063^{\mathrm{a}} \pm 0.0071$ \\
\hline
\end{tabular}

${ }_{\mathrm{AA}, \mathrm{BB}} P \leq 0.01,{ }^{\text {a }, \mathrm{bb}} \mathrm{P} \leq 0.05$

Table 4

Chickens' weight indices in individual stages of fattening, $\%$

\begin{tabular}{llllllll}
\hline Group & & Females & & Group & \multicolumn{3}{c}{ Males } \\
& Day 15 & Day 30 & Day 40 & & Day 15 & Day 30 & Day 40 \\
\hline C & 100 & 100 & 100 & C & 100 & 100 & 100 \\
GLY-P & 132.8 & 105.2 & 109.4 & GLY-P & 130.4 & 108.6 & 111.2 \\
GLY-R & 131.8 & 103.1 & 107.5 & GLY-R & 129.8 & 107.9 & 110.3 \\
\hline
\end{tabular}

\section{Feed consumption and conversion}

The overall consumption of feeding mixture during the 40-day fattening was (Table 5) $3.619 \mathrm{~kg}$ (C1), $4.003 \mathrm{~kg}$ (GLY-P1) and 3.977 (GLY-R1) in females, and $4.008 \mathrm{~kg}$ (C2), 4.484 (GLY-P2) and $4.548 \mathrm{~kg}$ (GLY-R2) in males.

Table 5

The consumption of feeding mixtures $(\mathrm{kg})$ and feed conversion $(\mathrm{kg} / \mathrm{kg})$ in chickens in control and experimental groups

\begin{tabular}{lcclcc}
\hline Group $P$ & Consumption & Conversion & Group O & Consumption & Conversion \\
\hline C1 & 3.619 & 1.78 & C2 & 4.008 & 1.73 \\
GLY-P1 & 4.003 & 1.80 & GLY-P2 & 4.484 & 1.74 \\
GLY-R1 & 3.977 & 1.82 & GLY-R2 & 4.548 & 1.78 \\
\hline
\end{tabular}


It is evident that it was higher in experimental chickens. Feed conversion was $1.78 \mathrm{~kg}$ (C1) and $1.80 \mathrm{~kg}$ (GLY-P1) and 1.82 (GLY-R1) in females, and $1.73 \mathrm{~kg}$ (C2), $1.74 \mathrm{~kg}$ (GLY-P2) and $1.78 \mathrm{~kg}$ (GLY-R2) in males. Increased growth intensity and the higher weight of chickens were associated with increased feed consumption and slightly decreased feed conversion in experimental groups of chickens. This finding was associated with a lower level of energy in experimental feeding mixtures that contained pure or raw glycerol (Table 6). Evidently, chickens in experimental groups with higher growth intensity have higher energy demands, consuming larger amounts of feeding mixture, particularly if it contains less energy. This was why feed conversion was lower in experimental chickens as compared to the control groups in a period between Day 30 and Day 40 of fattening where there were the highest differences in the content of energy in feeding mixtures (BR 3) (Table 6).

Table 6

The content of $\mathrm{BE}$ and $\mathrm{ME}_{\mathrm{d}}$ in feeding mixtures administered to chickens during fattening

\begin{tabular}{llccc}
\hline Mixture & Group & $\begin{array}{c}\mathrm{BE} \\
\mathrm{MJ} / \mathrm{kg}\end{array}$ & $\begin{array}{c}\mathrm{BE}^{*} \\
\mathrm{MJ} / \mathrm{kg}\end{array}$ & $\begin{array}{c}\mathrm{ME}_{\mathrm{d}} \\
\mathrm{MJ} / \mathrm{kg}\end{array}$ \\
\hline BR 1 & $\mathrm{C}$ & 16.6 & 18.6 & 12.20 \\
& GLY-P & 16.4 & 18.4 & 12.19 \\
& GLY-R & 16.3 & 18.3 & 11.91 \\
BR 2 & $\mathrm{C}$ & 17.1 & 19.0 & 12.79 \\
& GLY-P & 16.8 & 18.8 & 12.41 \\
& GLY-R & 16.6 & 18.6 & 12.40 \\
BR 3 & C & 17.1 & 19.0 & 12.61 \\
& GLY-P & 16.9 & 18.8 & 10.89 \\
& GLY-R & 16.7 & 18.6 & 10.86 \\
\hline
\end{tabular}

*BE related to $100 \%$ dry matter

In the course of fattening, feed consumption and conversion are changing, feed consumption per production of $1 \mathrm{~kg}$ of chickens live weight increases with the age of chickens. Such variations are illustrated in Graphs 1 and 2. An increasing value of feed conversion during the fattening period was observed in all groups of females (Figure 1). The highest values of feed conversion were found in females between Day 30 and Day 40 of fattening. At the end of fattening, feed conversion was somewhat lower in experimental groups as compared to the control group. On the other hand, a slight decrease in feed conversion was found in control females between Days 15 and 30 as compared to experimental groups. Similar changes in feed conversion were also observed in males (Figure 2), with the highest values of feed conversion being observed in males from Day 30 to 40 of fattening, being slightly higher as compared to the control group of chickens. It follows from the results that the longer the fattening process is, the higher consumption of a feeding mixture per unit of production is seen. 


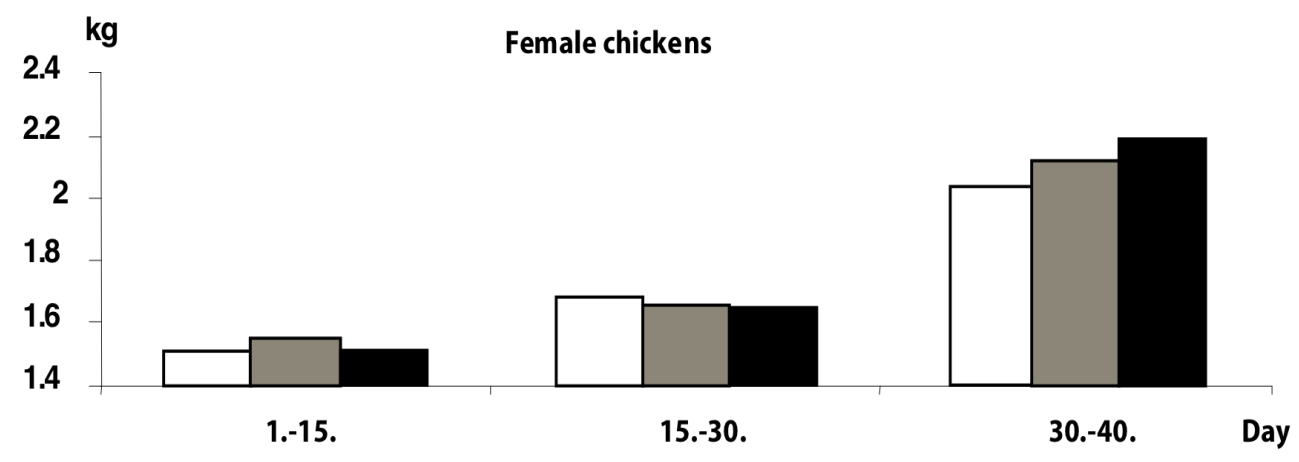

C: control group (white), E 1: experimental group 1 (grey), E 2: experimental group 2 (black)

Figure 1

Feed conversion in female chickens in individual stages of development

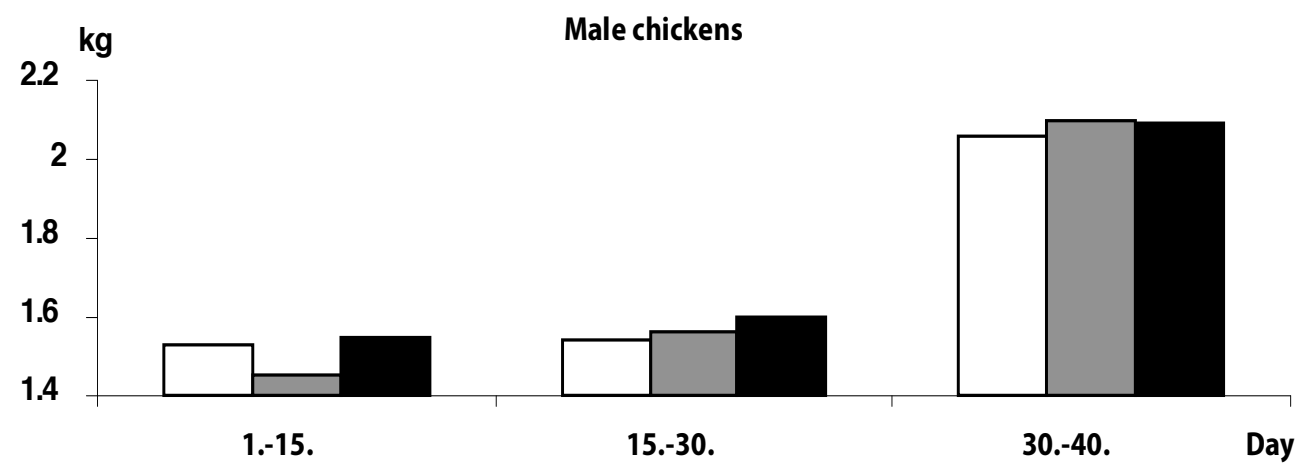

C: control group (white), E 1: experimental group 1 (grey), E 2: experimental group 2 (black)

Figure 2

Feed conversion in male chickens in individual phases of development

\section{Examination of the state of chickens health}

The state of chickens' health can be evaluated positively. Control chickens and experimental chickens did not show any clinical symptoms of any disease during the experiment. As reported by Simon et al. (1997), the levels of glycerol as high as $25 \%$ were associated with pathological changes in organs, and had a negative impact on the performance of broiler chickens. Mortality was minimal, and was usually associated with congenital defects in chickens aged up to 5 days. One chicken died in the control group of females and one chicken also died in the GLY-P group. Similarly, one chicken died in the control group of males and one in the GLY-R group of males. 
The weight and yield of the liver

Macroscopic examination was selected as a post-mortem parameter to examine chickens health. Symptoms of various diseases are manifested in the liver, for example metabolic disorders that are usually associated with dietetic errors. The liver from experimental and control chickens did not show abnormalities in colour, shape, structure or consistence. The weight of liver in experimental chickens was lower as compared to that in control chickens. Differences between mean values were statistically inconclusive in both females and males (Table 7). The situation for the yield of the liver is different (Table 7). The liver in experimental chickens showed lower values as compared to control chickens, in both females and males. The difference between the mean value in control chickens and the mean value in chickens in the GLY-R group was statistically highly significant $(P \leq 0.01)$. Males showed a significant difference $(P \leq 0.01)$ between the control group and the GLY-R group and also between the control group and the GLY-P experimental group.

Table 7

Mean weight and yield of the liver in broiler chickens $(x \pm S D)$

\begin{tabular}{|c|c|c|c|c|c|c|}
\hline & C & GLY-P & $\begin{array}{l}\text { Females } \\
\text { GLY-R }\end{array}$ & C & $\begin{array}{l}\text { Males } \\
\text { GLY-P }\end{array}$ & GLY-R \\
\hline $\begin{array}{l}\text { Weight } \\
\text { of the liver, } \mathrm{g}\end{array}$ & $35.54 \pm 7.590$ & $35.05 \pm 6.486$ & $32.37 \pm 5.858$ & $41.87 \pm 8.016$ & $37.21 \pm 6.585$ & $37.21 \pm 8.240$ \\
\hline $\begin{array}{l}\text { Yield } \\
\text { of the liver, \% }\end{array}$ & $1.82^{A} \pm 0.634$ & $1.59 \pm 0.292$ & $1.47^{A} \pm 0.215$ & $1.90^{A B} \pm 0.605$ & $1.45^{\AA} \pm 0.256$ & $1.46^{B} \pm 0.271$ \\
\hline
\end{tabular}

\section{Carcass value of chickens}

Parameters such as carcass weight (CW) and carcass yield (CY) can be used to assess the carcass value of broiler chickens.

\section{Carcass weight}

One positive finding is that the $50 \%$ substitution of soybean oil with glycerol resulted in a statistically significantly higher carcass weight in experimental chickens, which strongly correlates with a significantly higher live weight (Table 8). No significant differences were found between experimental groups with pure and raw glycerol in a diet. Differences in the mean carcass weight between the group of control chickens and the groups of experimental chickens were highly significant $(P \leq 0.01)$. Generally, carcass weight was higher in males as compared to females.

\section{Carcass yield}

The evaluation of slaughter values also included the determination of carcass yield (Table 8). It is obvious that there are no differences in carcass yield between control and experimental groups; this means that the relative development of individual tissues and organs was not affected by glycerol. Although carcass weight in experimental groups was higher, differences 
in carcass yield between the groups were not significant. Carcass weight did not affect substantially carcass yield in females and males. Carcass yield was investigated by Oplt (2001) who reported carcass yield for three hybrid combinations of broiler chickens such as ROSS 308-73.45\%, COBB-72.97\% and HYBRO-73.18\%. The mean values of carcass yield found in the present experiment for ROSS 308 broiler chickens varied in a range of $71.73-72.61 \%$, being comparable with the findings reported by Nováková (1991), Skřivan \& Tůmová (1990) Jaturasitha et al. (2008), Lazar (1990) pointed out to a marked effect of the hybrid combination of broiler chickens on carcass parameters. The fact that carcass yield increases with the prolongation of the fattening period has been confirmed by a number of authors (Zelenka et al. 1989, Skřivan \& Tůmová 1990). Increased carcass yields of about $74 \%$ were reported by Šafuj et al. (2001) whereas lower values were reported for example by Shahin \& Abd El Azeem $(2005,2006)$. Zelenka et al. (1989) found $65.16 \%$ (in female chickens) and $70.56 \%$ (in male chickens). There is a relatively small number of studies in scientific literature that deal with the use of glycerol in the nutrition of farm animals. However, it can be concluded that glycerol obtained in the processing of rapeseed is and will be in the future a suitable energy component to serve as an additive in feeds for farm animals. Another positive finding is that glycerol improves the technological and hygienic quality of granules, as reported by Schröder \& Südekum (1999). There are a number of issues associated with the use of glycerol in the nutrition of animals which should be subjected to intensive research.

Table 8

Slaughter characteristics of broiler chickens $(x \pm S D)$

\begin{tabular}{ccccccc}
\hline \multicolumn{5}{c}{ Females } & \multicolumn{3}{c}{ Males } \\
& $\mathrm{C}$ & GLY-P & GLY-R & $\mathrm{C}$ & GLY-P & GLY-R \\
\hline $\mathrm{CW}, \mathrm{g}$ & $1461^{\mathrm{AB}} \pm 250.13$ & $1612^{\mathrm{A}} \pm 158.7$ & $1585^{\mathrm{B}} \pm 148.21$ & $1662^{\mathrm{A}} \pm 319.26$ & $1850^{\mathrm{A}} \pm 200.53$ & $1837^{\mathrm{B}} \pm 214.41$ \\
$\mathrm{CY}, \%$ & $71.94 \pm 3.582$ & $72.61 \pm 1.543$ & $72.17 \pm 1.640$ & $71.73 \pm 0.959$ & $71.77 \pm 1.517$ & $72.24 \pm 1.840$ \\
\hline
\end{tabular}

${ }_{\mathrm{AA}, \mathrm{BB} P} \leq 0.01, \mathrm{CW}$ : carcass weight, $\mathrm{CY}$ : carcass yield

\section{Acknowledgements}

Financial support from the Ministry of Education, Youth, and Sports of the Czech Republic (Grant No MSMT 6215712402) is gratefully acknowledged.

\section{References}

Anonymous author (2003) Regulation No. 318/2003 of 12 September 2003 amending Regulation No. 54/2002 Coll. that specifies the safety requirements concerning the identity and purity of additives. E 422 Glycerol., 5258

Barteczko J, Kaminski J (1999) The effect of glycerol and vegetable fat on some physiological indices of the blood and excess of fat in broiler carcasses. Ann Warsaw Agricult Univ Anim Sci 36, 197-209

Carew LB, Foss DC (1974) Glycerol in diet of chicks. Poult Sci 53, 1907-1907

Cerrate S, Yan F, Wang Z, Coto C, Sacakli P, Waldroup PW (2006) Evaluation of glycerine from biodiesel production as a feed ingredient for broilers. Int J Poult Sci 5, 1001-1007

Demarne Y, Perazacastro CE, Henry Y, Flanzy J (1977) Effects on lipid fatty-acid composition in different adipose deposits of pig ingesting glycerol tri-dodecanoate (Tri C12=0). Ann Biol Anim Biochim Biophys $17,137-146$ 
Dozier WA, Kerr BJ, Corzo A, Kidd MT, Weber TE, Bregendal K (2008) Apparent metabolizable energy of glycerin for broiler chickens. Poult Sci 87, Suppl. 1, 153-153

Emmanuel B, Berzins R, Robblee AR (1983) Rates of entry of alanine and glycerol and their contribution to glucose synthesis in fasted chickens. Br Poult Sci 24, 565-571

Jaturasitha S, Kayan A, Wicke M (2008) Carcass and meat characteristics of male chickens between Thai indigenous compared with improved layer breeds and their crossbred. Arch Tierz 51, 283-294

Lazar V (1990) Poultry rearing. University of Agriculture, Brno, 210 p. [in Czech]

Lin MH, Romsos DR, Leveille GA (1976) Effect of glycerol on lipogenic enzyme-activities and on fatty-acid synthesis in rat and chicken. J Nutr 106, 1668-1677

Neville WJ, MacPherson JW, King GJ (1970) The contraceptive action of glycerol in gilts. J Anim Sci 31, 227

Neville WJ, MacPherson, JW, Reinhart B (1971) The contraceptive action of glycerol in chickens. Poult Sci 50, $1411-1415$

Nováková S (1991) The quality of poultry for slaughter and poultry meat. University of Agriculture, Brno, Czechoslovakia [in Czech]

Oplt J (2001) Czech poultry management - history and the current state. Náš chov 61, 36-37 [in Czech]

Renner R, Elcombe A (1964) Factors affecting utilization of carbohydrate free diets by nutrition. 2. Level of glycerol. J Nutr 84, 327-330

Schröder A, Südekum KH (1999) Glycerol as a by-product of biodiesel production in diets for ruminants. Proceedings of the 10th International Rapeseed Congress, Canberra, Australia. http://www.regional.org. au/au/gcirc/1/241.htm [last accessed 23.05.2011]

Shahin KA, Abd El Azeem F (2005) Effect of breed, sex and diet and their interaction on carcass composition and tissue weight distribution of broiler chickens. Arch Tierz 48, 612-626

Shahin KA, Abd El Azeem F (2006) Effect of breed, sex and diet and their interaction on fat deposition and partitioning among depots of broiler chickens. Arch Tierz 49, 181-193

Simon A, Bergner H, Schwabe M (1996) Glycerol-feed ingredient for broiler chickens. Arch Anim Nutr 49, 103112

Simon A, Schwabe M, Bergner H (1997) Glycerol supplementation to broiler rations with low crude protein content. Arch Anim Nutr 50, 271-282

Skřivan M, Tůmová E (1990) Slaughter performance of Hybro, Ross 208 and ROSS PM 3 male chickens aged 5-8 weeks. Ziv Vyr 35, 1049-1257

Šafuj P, Přibyl J, Soukupová Z (2001) The development of broiler performance in fattening tests in a period of 1984-1997. Náš chov 61, 36-37 [in Czech]

Westfall FD, Howarth B (1976) Effect of time of glycerol deposition on fertility of chickens. Poult Sci 55, 21052106

Zelenka J, Elnsabbach MT, Lazar V (1989) Growth, feed conversion and slaughter analysis of chickens fattened to heavy weight. Ziv Vyr 34, 989-996

Received 3 May 2010, accepted 23 February 2011.

Corresponding author:

Pavel Suchý

email: suchyp@vfu.cz

Department of Nutrition, Animal Husbandry, and Animal Hygiene, Faculty of Veterinary Hygiene and Ecology, University of Veterinary and Pharmaceutical Sciences Brno, Palackého 1/3, 612 Brno, Czech Republic 